REALA, número 14, octubre de 2020

Sección: ESTUDIOS BREVES

Recibido: 12-08-2020

Modificado: 17-09-2020

Aceptado: 18-09-2020

DOI: https://doi.org/10.24965/reala.i14.10852

Páginas: 104-120

\title{
La infracción de abandono de animales domésticos en la Ley de Seguridad Ciudadana y en otras disposiciones penales y administrativas: concurrencia de normas punitivas y de ilícitos
}

\section{The domestic animals abandonment infringement in the citizen security law and other criminal and administrative provisions: punitive rules for coexistence and concurrent offences}

Carmen Martín Fernández

Universidad de Córdoba (España)

ORCID: https://orcid.org/0000-0003-0118-7746

d12mafec@uco.es

\section{NOTA BIOGRÁFICA}

Becaria FPU del MEC en el Área de Derecho Administrativo de la Universidad de Córdoba. Principales líneas de investigación: Derecho Administrativo sancionador, seguridad pública y Derecho de la competencia.

\section{RESUMEN}

El art. 37.16 de la Ley Orgánica 4/2015 de Protección de la Seguridad Ciudadana (LOPSC) tipifica como infracción administrativa el abandono de animales domésticos en condiciones en que pueda peligrar su vida. En este trabajo se pone de manifiesto la inadecuada redacción del precepto (copia literal de una antigua falta del Código Penal) y se reflexiona acerca de cuál es o debe ser su bien jurídico protegido. Para finalizar, se analizan los concursos de infracciones y de normas punitivas que pueden plantearse entre este precepto de la LOPSC y otras normas que castigan el abandono de animales domésticos.

\section{PALABRAS CLAVE}

Abandono; animales; infracción; concursos de normas; concurso de infracciones; bien jurídico protegido; seguridad ciudadana.

\begin{abstract}
The art. 37.16 of Organic Law 4/2015 on the Protection of Citizen Security (LOPSC), classifies the abandonment of domestic animals in conditions that could endanger their lives as an administrative offence. This paper shows the inadequate drafting of the precept (a copy of a repealed penal offence) and a reflection on what is or should be its protected legal asset. Finally, it is analysed the concurrent offences and the rules for coexistence between this precept of the LOPSC and other norms that punish the abandonment of domestic animals.
\end{abstract}

\section{KEYWORDS}

Abandonment; animals; administrative offence; rules for coexistence; concurrent offences; protected legal asset; citizen security. 
REALA. Nueva Época - N. 14, octubre 2020 - ISSN: 1989-8975 - DOI: https://doi.org/10.24965/reala.i14.10852 - [Págs. 104-120]

\begin{abstract}
SUMARIO
INTRODUCCIÓN: EL ART. 37.16 LOPSC. 1. EL BIEN JURÍDICO PROTEGIDO EN LA INFRACCIÓN DE ABANDONO DE ANIMALES DOMÉSTICOS DE LA LOPSC. 2. LA ACCIÓN QUE TIPIFICA ESTA INFRACCIÓN: EL ABANDONO. 2.1. EL ABANDONO ¿EN CONDICIONES EN QUE PUEDA PELIGRAR LA VIDA DEL ANIMAL? 2.2. EL ABANDONO REPROCHABLE EN VIRTUD DE LA LOPSC SOLO DEBE SER EL FÍSICO, NO EL ASISTENCIAL. 2.3. EL ABANDONO EN ESPACIOS PÚBLICOS O PRIVADOS DE USO PÚBLICO O EN CONDICIONES QUE PERMITEN AL ANIMAL ACCEDER A DICHOS ESPACIOS. 3. SU RELACIÓN CON EL DELITO DE ABANDONO DE ANIMALES DOMÉSTICOS PREVISTO EN EL ART. 337 BIS CP. 4. SU RELACIÓN CON LAS INFRACCIONES DE ABANDONO DE LAS LEYES AUTONÓMICAS DE PROTECCIÓN ANIMAL. 5. SU RELACIÓN CON LAS INFRACCIONES DE ABANDONO DE LAS ORDENANZAS DE CONVIVENCIA CIUDADANA Y DE PROTECCIÓN ANIMAL. 6. LA POSIBLE CONCURRENCIA DE NORMAS PUNITIVAS Y DE INFRACCIONES SOBRE ABANDONO DE ANIMALES DOMÉSTICOS. 6.1. DISTINCIÓN ENTRE CONCURSOS DE NORMAS PUNITIVAS Y DE ILÍCITOS. 6.2. EL ART. 37.16 LOPSC Y EL ART. 337 BIS CP. 6.3. EL ART. 37.16 LOPSC Y LAS INFRACCIONES DE ABANDONO DE LA NORMATIVAAUTONÓMICA. 6.4. EL ART. 37.16 LOPSC Y LAS INFRACCIONES DE ABANDONO DE LAS ORDENANZAS DE CONVIVENCIA CIUDADANA Y DE PROTECCIÓN ANIMAL. CONCLUSIONES. REFERENCIAS BIBLIOGRÁFICAS.
\end{abstract}

\title{
INTRODUCCIÓN: EL ART. 37.16 LOPSC
}

El art. 37.16 de la Ley Orgánica 4/2015, de 30 de marzo, de Protección de la Seguridad Ciudadana (en adelante, LOPSC), tipifica como infracción leve «Dejar sueltos o en condiciones de causar daños animales feroces o dañinos, así como abandonar animales domésticos en condiciones en que pueda peligrar su vida».

Como puede observarse, el precepto tipifica en realidad dos infracciones: por una parte, dejar sueltos o en condiciones de causar daños animales feroces o dañinos y, por otra parte, abandonar animales domésticos en condiciones en que pueda peligrar su vida. Infracciones totalmente distintas y que únicamente tienen en común su relación con los animales y -presuntamente- con la seguridad ciudadana. La primera de ellas proviene de la anterior falta del art. $631.1 \mathrm{CP}$, que castigaba con multa de quince a treinta días a los dueños o encargados de la custodia de animales feroces o dañinos que los dejaren sueltos o en condiciones de causar mal. Mientras que la segunda es idéntica a la antigua falta del art. $631.2 \mathrm{CP}$, que castigaba con multa de quince días a dos meses a quienes abandonasen a un animal doméstico en condiciones en que pudiera peligrar su vida o integridad.

A partir de aquí, me centraré en esta segunda infracción y en los problemas jurídicos que puede suscitar dada su inadecuada redacción.

\section{EL BIEN JURÍDICO PROTEGIDO EN LA INFRACCIÓN DE ABANDONO DE ANIMALES DOMÉSTICOS DE LA LOPSC}

Parece que, en principio, todas las infracciones que prevea una Ley de seguridad ciudadana debieran de tener como bien jurídico protegido la propia seguridad ciudadana. Como mucho, quizás podría aceptarse que el bien jurídico protegido fuera el más general orden público o, al menos, alguno de sus componentes específicos (la seguridad, salubridad o tranquilidad públicas) ${ }^{1}$. Así lo insinúa Rebollo Puig cuando, al analizar la finalidad perseguida por la LOPSC y contrastarla con la de sus predecesoras -la Ley Orgánica 1/1992, de 21 de febrero, sobre Protección de la Seguridad Ciudadana, la Ley 45/1959, de 30 de julio, de Orden Público, y la Ley de Orden Público de 1933-, explica que «las leyes de orden público nunca se han ocupado de toda la actividad administrativa de limitación realizada con el fin de garantizar el orden público, sino solo de una parte que, en esencia, coincide con el contenido de las posteriores leyes de seguridad ciudadana» (Rebollo Puig, 2019: 49). Por ejemplo, no se han ocupado de los problemas de salubridad pública, porque para ellos

Esto, claro está, si es que entendemos que una ley con tal denominación en realidad pretende alcanzar un objetivo más amplio: proteger el orden público, o al menos una parte del mismo, y no solo la seguridad ciudadana. Antes de avanzar, resulta necesario aclarar qué se ha entendido tradicionalmente por orden público. Hauriou lo definió como un orden material y exterior, un estado de hecho contrario al desorden (HAURIOU, 1914: 517). Y la doctrina mayoritaria considera que se trata de un concepto jurídico indeterminado, pero dentro del cual pueden comprenderse los siguientes elementos: la seguridad, la salubridad, la tranquilidad y la moralidad públicas (REBOLLO PUIG, 2017b: 28-29). 
REALA. Nueva Época - N. ${ }^{14}$, octubre 2020 - ISSN: 1989-8975 - DOI: https://doi.org/10.24965/reala.i14.10852 - [Págs. 104-120]

La infracción de abandono de animales domésticos en la Ley de seguridad ciudadana y en otras disposiciones penales y administrativas...

Carmen Martín Fernández

existen ya otras leyes específicas. Tampoco los ha abordado la LOPSC, lo que fácilmente se intuye de su propio título. También han solido quedar fuera de las Leyes de orden público los aspectos relacionados con la moralidad pública, aunque Rebollo reconoce que algunas de las infracciones de la LOPSC ponen de relieve la conexión existente con este aspecto del orden público².

En definitiva, lo que ha ocurrido es que, aunque las leyes de orden público hayan pasado a denominarse leyes de seguridad ciudadana, quizás por el recelo que la sola mención del orden público ha suscitado en gran parte de la doctrina española de un tiempo a esta parte, su contenido no es tan distinto, por lo que en muchas infracciones de la LOPSC puede comprobarse cómo no solo se protegen las personas y los bienes en sentido estricto, sino también otros elementos del orden público, como la tranquilidad o la convivencia ciudadanas, el buen funcionamiento de las instituciones y la moralidad pública. Al igual que Alarcón Sotomayor, creo que es razonable que así sea, «no ya porque la cláusula de orden público lo justifique -como defiende Rebollo-, sino, más claramente, porque lo ampara la competencia exclusiva que tiene el Estado sobre la seguridad pública» (Alarcón Sotomayor, 2019: 332). Competencia en virtud de la cual se han dictado las disposiciones de la LOPSC, salvo las relativas a las armas y explosivos.

Es por todo esto que digo por lo que, en lo que concierne a la infracción del art. 37.16 LOPSC y al bien jurídico que allí se protege, son plausibles dos interpretaciones distintas:

- Entender que el bien jurídico protegido en este precepto es la seguridad ciudadana en sentido estricto, por el peligro que para ella comporta que animales domésticos sean abandonados y puedan deambular libremente por espacios públicos sin el control de ninguna persona y devenir asilvestrados.

- Considerar que el bien jurídico protegido es la moralidad pública -como componente específico del orden público-, que puede resultar dañada cuando se produce el abandono de un animal doméstico en condiciones en que pudiera peligrar su vida.

Lo que en ningún caso parece que puede interpretarse, a pesar de la redacción del precepto, es que el bien jurídico protegido sea el bienestar o la protección animal. En primer lugar, porque es dudoso que una Ley -como la LOPSC- dictada en virtud de la competencia estatal exclusiva del art. 149.1.29 CE en seguridad pública pueda entrar a proteger a los animales domésticos. En segundo lugar, porque más dudoso aún es que el Estado sea competente para legislar en favor de la protección animal ${ }^{3}$. Y, en tercer lugar, y, sobre todo, porque el CP y las leyes autonómicas de protección animal (e incluso muchas ordenanzas) ya se encargan de castigar el abandono de animales desde la perspectiva de la protección animal y de los intereses generales que resultan perjudicados con dicha conducta.

Es, por ello, que, a mi juicio, solo es posible interpretar que este precepto de la LOPSC se ha tipificado para proteger la seguridad ciudadana por los peligros que para ella entraña el abandono de animales domésticos. Ni siquiera creo que tenga mucho sentido sostener que con él se garantiza la moralidad pública, por razones que después explicaré. En cualquier caso, reconozco que la interpretación que sostengo en este trabajo es acrobática y acreedora de ciertos problemas, pues alguien incluso podría afirmar que con ella se vulnera el principio de legalidad en su vertiente de tipicidad. A pesar de ello, será la postura que defienda por ser la única que, creo, garantiza una mínima coherencia.

Pero adelanto ya que lo que sí podría aceptarse es que, como muchas veces ocurre con otras infracciones de la LOPSC, en el art. 37.16 LOPSC se protege de forma colateral otro bien jurídico ${ }^{4}$. En este sentido, sí que creo que podría sostenerse que se protege la vida de los animales domésticos y la moralidad pública que resulta perturbada en caso de abandono de animales. Pero, como digo, solo de forma colateral, pues, tal y como he advertido, no es plausible considerar que sea este el bien jurídico protegido -principal y directamente- por el

2 Se refiere, por ejemplo, al art. 37.5 LOPSC que tipifica «ejecutar actos de exhibición obscena» y al art. 36.11 LOPSC, relativo a la solicitud o aceptación de servicios sexuales retribuidos, en el que trasluce, dice, «cierta protección de la moralidad pública, disfrazada, como es hoy habitual, de defensa de los menores» (REBOLLO PUIG, 2019: 76).

3 Sería dudoso que pudiera el legislador estatal regular esta materia con carácter general, dada la presunta inexistencia de un título competencial que la ampare. La competencia relativa al medio ambiente no parece adecuada dada su perspectiva antropocéntrica (DOMÉNECH PASCUAL, 2004: 134-135). Aunque algunos autores defienden el recurso a la misma porque consideran que esa visión antropocentrista del medio ambiente ya ha sido superada (PÉREZ MONGUIÓ, 2005: 221-227).

4 En el caso del art. 36.23 LOPSC, por ejemplo, el bien jurídico protegido es la seguridad ciudadana, pero colateralmente resulta protegida la función policial y, a veces, incluso los derechos de los propios policías (MARTíN FERNÁNDEZ, 2019: 577-580). Y lo mismo parece suceder con la infracción de ocupación de inmuebles del art. 37.7 LOPSC: el bien jurídico protegido vuelve a ser la seguridad ciudadana, pero colateralmente resulta protegido el patrimonio inmobiliario (PIZARRO NEVADO, 2019: 459-499). 
REALA. Nueva Época - N. ${ }^{14}$, octubre 2020 - ISSN: 1989-8975 - DOI: https://doi.org/10.24965/reala.i14.10852 - [Págs. 104-120]

precepto. Esto es lo que creo que debe interpretarse dada la redacción del artículo en cuestión, que tipifica como infracción el abandono de animales domésticos «en condiciones en que pueda peligrar su vida». Si lo único que se protegiera fuera la seguridad ciudadana ningún sentido tendría incluir esa condición en el precepto, sino que bastaría con que se tipificara como infracción el abandono de animales domésticos -si acaso habría que añadir «en lugares públicos», como luego explicaré-, por el peligro que puede suponer para dicho valor el hecho de que los animales domésticos abandonados se conviertan en asilvestrados y deambulen libremente por espacios públicos. De hecho, creo que otra redacción en esta dirección que apunto sería más adecuada y así lo defenderé, pero me centraré en estudiar la vigente actualmente y en tratar de realizar una interpretación correctora de la misma que la haga compatible con el que, a mi juicio, debe ser su bien jurídico protegido.

\section{LA ACCIÓN QUE TIPIFICA ESTA INFRACCIÓN: EL ABANDONO}

La conducta típica de esta infracción prevista en el art. 37.16 LOPSC coincide prácticamente con la que tipificaba la anterior falta del art. 631.2 CP: abandonar animales domésticos en condiciones en que pueda peligrar su vida (o su integridad, que añadía el precepto penal). También coincide casi por completo con la conducta tipificada como delito por el actual art. 337 bis $\mathrm{CP}^{5}$.

\subsection{El abandono ¿en condiciones en que pueda peligrar la vida del animal?}

El art. 37.16 LOPSC, en puridad, no tipifica como infracción leve cualquier tipo de abandono, sino única y exclusivamente aquel que se produce en unas condiciones tales que pueden poner en peligro la vida del animal. De igual forma hace el art. 337 bis CP y hacía el art. 631.2 CP. No obstante, y como ya he advertido antes, parece que no tiene mucho sentido que un precepto de una ley de seguridad ciudadana se preocupe por la vida o la integridad de los animales. Por eso, creo que hubiera sido más acorde a la finalidad y al ámbito de la LOPSC que la infracción hubiera consistido, simplemente, en «abandonar animales domésticos en espacios públicos». Esto último, relativo a los espacios públicos, trataré de justificarlo a continuación. Antes voy a detenerme en las razones por las que no creo necesario que el precepto exija que el abandono suponga un peligro para la vida del animal.

El abandono de animales domésticos supone un peligro para la seguridad ciudadana porque ese animal doméstico puede convertirse, como consecuencia del abandono, en un animal asilvestrado. Un animal asilvestrado es, según la RAE, un animal doméstico o domesticado que vive en las condiciones de un animal salvaje. El Diccionario Panhispánico del Español Jurídico lo define como «animal de procedencia doméstica que está establecido y se mueve libremente en el medio natural y no vive ni se cría bajo tutela, manejo ni supervisión de las personas» ${ }^{6}$. Es obvio, por tanto, por qué estos animales suponen un peligro para la seguridad ciudadana: deambulan por las calles, por los espacios públicos, sin persona alguna que los controle, haciendo y deshaciendo a su antojo y puede que actuando con agresividad o provocando accidentes de tráfico. De eso es de lo que debe preocuparse una ley de seguridad ciudadana. No de si los animales se encuentran en peligro o mueren a causa de ser abandonados. Esto, por muy reprochable que sea, debe ser perseguido por otras Leyes. Precisamente por eso, el art. 337 bis CP tipifica como delito leve el abandono de animales en condiciones en que pueda peligrar su vida o integridad. Allí sí que tiene sentido que se salvaguarde el bienestar animal como parte de los intereses generales, pero no en una ley concreta que solo persigue garantizar la seguridad ciudadana -y si acaso algunos otros elementos del orden público-. Lo mismo ocurre con las leyes autonómicas de protección animal. Todas las CC.AA cuentan con una Ley de protección animal que tipifica como infracción el abandono de animales.

Todo esto no hace sino confirmar que la redacción de la infracción del art. 37.16 carece de sentido en una Ley de seguridad ciudadana ${ }^{7}$. Primero, porque es dudoso e incoherente que una ley estatal de segu-

\footnotetext{
5 Art. 337 bis CP: «El que abandone a un animal de los mencionados en el apartado 1 del artículo anterior en condiciones en que pueda peligrar su vida o integridad será castigado con una pena de multa de uno a seis meses. Asimismo, el juez podrá imponer la pena de inhabilitación especial de tres meses a un año para el ejercicio de profesión, oficio o comercio que tenga relación con los animales y para la tenencia de animales».

6 Disponible en versión electrónica en: $h$ ttps://dej.rae.es/.

7 Precisamente por esto, el Grupo Parlamentario Vasco presentó una enmienda de modificación al art. 37.17 del Proyecto de Ley (equivalente al art. 37.16 LOPSC) para que se eliminara toda alusión al maltrato o abandono de animales domésticos, afirmando que si dichas figuras se despenalizaran deberían sancionarse «en las leyes de protección de animales, no en la de seguridad ciudadana».
} 
REALA. Nueva Época - N. 14, octubre 2020 - ISSN: 1989-8975 - DOI: https://doi.org/10.24965/reala.i14.10852 - [Págs. 104-120]

La infracción de abandono de animales domésticos en la Ley de seguridad ciudadana y en otras disposiciones penales y administrativas...

Carmen Martín Fernández

ridad ciudadana pueda entrar a proteger a los animales; segundo, porque se solapa por completo con el delito leve del art. 337 bis CP; tercero, porque la finalidad que parece perseguir ya es perseguida por dicho precepto del CP y por las diecisiete leyes autonómicas de protección animal; y cuarto, porque no castiga siempre y en todo caso el abandono, sino únicamente cuando el abandono pone en peligro al animal y, para eso, ya existen, como acabo de mencionar, otras vías de protección.

\subsection{El abandono reprochable en virtud de la LOPSC solo debe ser el físico, no el asistencial}

La acción que es constitutiva de infracción se definía y se define en torno al verbo «abandonar». Según la RAE, una de las acepciones de «abandonar» es «Dejar solo algo o a alguien alejándose de ello o dejando de cuidarlo». De ello se deduce que abandonar un animal doméstico consiste en dejar solo al animal y alejarse de él o dejar de cuidarlo. Como vemos, son dos las posibles conductas constitutivas de abandono: abandonar físicamente al animal, desprendiéndose de él, dejándolo solo en algún lugar y alejándose del mismo; o abandonar asistencialmente al animal, dejando de proporcionarle alimentación, higiene o los cuidados que requiera.

La doctrina penalista, que analizó la falta del art. 631.2 CP y que ha estudiado el actual delito del art. 337 bis $\mathrm{CP}$, considera que la conducta típica consiste en «dejar desprotegido al animal, dejarlo en situación de desamparo» (Gómez Tomillo, 2015: 189; Hava García, 2011: 304; Mesías Rodríguez, 2018: 85). Y esta situación puede acontecer bien porque se ha llevado a cabo un abandono físico o bien porque se han inobservado las obligaciones que como garante se tienen respecto al animal, lo cual se conoce como abandono funcional. Por eso, la doctrina llegó a la conclusión de que el abandono podía ser activo u omisivo. Y lo mismo ha declarado la jurisprudencia ${ }^{8}$.

Sin embargo, teniendo en cuenta que en la actualidad se trata de una infracción de una ley de seguridad ciudadana y, por tanto, partiendo de la interpretación sistemática y teleológica del precepto defendida en epígrafes anteriores, creo que el art. 37.16 LOPSC únicamente debe castigar el abandono físico -en lugares públicos, como explicaré en el apartado siguiente- por cuanto es el único que puede poner en peligro la seguridad ciudadana. A mi parecer, los demás tipos de abandono (abandono asistencial y abandono físico en lugares que no sean públicos) deberían ser castigados en virtud de las leyes autonómicas de protección animal y, en última instancia, por los jueces penales ex art. 337 bis $\mathrm{CP}$, pues no ponen en peligro a las personas y los bienes, sino únicamente la integridad física del animal.

\subsection{El abandono en espacios públicos o privados de uso público o en condiciones que permiten al animal acceder a dichos espacios}

En el tipo penal -del art. 337 bis CP-, como se protege primariamente al animal ${ }^{9}$, lo relevante es que el abandono se produzca en condiciones tales que pongan en peligro su vida o su integridad. En las leyes administrativas de protección de los animales, que son autonómicas, el objeto de tutela son también los animales en sí mismos, así que lo esencial es que acontezca el abandono, con indiferencia de las circunstancias en que se produzca, porque cualquiera de ellos conlleva siempre una desprotección del animal y un peligro, aunque sea mínimo, para el mismo. En la LOPSC, según se ha explicado antes, también puede parecer que lo importante es que el abandono conlleve un peligro para la vida del animal, pero lo más coherente sería interpretar que el precepto únicamente pretende castigar el abandono físico que se produzca en lugares

8 La SAP de A Coruña n. ${ }^{\circ}$ 244/2017, de 29 de diciembre (JURI2018/48077), citando la definición de «abandonar» de la RAE («dejar, desamparar a una persona o cosa»), explicó: "gramaticalmente el abandono puede entenderse tanto desde un punto de vista activo como omisivo, bastando con que la conducta cause desamparo del animal». Igual pronunciamiento contienen, entre otras muchas, la SAP de Álava n. ${ }^{\circ} 82 / 2012$, de 6 de marzo (JURI2014I144878), la SAP de Segovia n. ${ }^{\circ}$ 23/2007, de 5 de marzo (ARPI2007\180), la SAP de Lleida n. ${ }^{\circ}$ 97/2008, de 6 de marzo (JURI2008/143151), y la SAP de Granada n. ${ }^{\circ}$ 265/2008, de 25 de abril (JURl2009l20736), las cuales, además, explicaron: «habrá que entender que el abandono se puede producir porque se deje al animal o porque se le coloque en situación de desamparo, tanto por la acción directa de expulsarle como por la omisiva de no prestarle la menor asistencia y alimentación cuando lo necesite». Con relación al actual art. 337 bis CP, puede citarse como ejemplo la SAP de Navarra n. ${ }^{\circ} 82 / 2018$, de 10 de abril (JURI2018|181976), que afirmó: «la acción tipificada alcanza no sólo al abandono material, sino también aquella conducta omisiva que objetivamente revela que el animal pese a no haber sido abandonado materialmente se encuentra en una situación total de abandono en su cuidado y atención».

9 Pérez Monguió pone de manifiesto que el art. 631.2 CP (ya derogado y que ha dado paso tanto a la infracción del art. 37.16 LOPSC como al delito leve del art. 337 bis CP) incorporó a nuestro Código Penal los principios de bienestar animal pues su bien jurídico protegido era el animal y su integridad y no valores humanos (PÉREZ MONGUIÓ, 2005: 363). 
REALA. Nueva Época - N. ${ }^{14}$, octubre 2020 - ISSN: 1989-8975 - DOI: https://doi.org/10.24965/reala.i14.10852 - [Págs. 104-120]

La infracción de abandono de animales domésticos en la Ley de seguridad ciudadana y en otras disposiciones penales y administrativas...

públicos o privados de uso público o en condiciones que permitan al animal acceder a dichos lugares. Y ello porque solo este tipo de abandono pone en peligro la seguridad ciudadana. Porque, ¿qué riesgo conlleva para la seguridad ciudadana que un sujeto abandone en el interior de su casa a un perro y que el animal muera por inanición? Creo que ninguno ${ }^{10}$. Si acaso, existirían riesgos para la salud pública y, precisamente, por ello, la Ley $8 / 2003$, de 24 de abril, de sanidad animal, en su art. 84.20, tipifica como infracción grave el abandono de animales o de sus cadáveres que entrañen un riesgo sanitario para la sanidad animal o para la salud pública.

En mi opinión, el único abandono que debería castigar una ley de seguridad ciudadana como la actual es el que pueda originar el denominado «vagabundeo» del animal. Pérez Monguió explica que «el problema de abandono y el posterior vagabundeo, sobre todo de perros, ha llegado a ser de tal magnitud en algunos lugares que ha llegado hasta la Comisión Europea a través de la pregunta E-2218/01, de 24 de julio, en la que se hacía mención que solo en Bucarest, Rumanía, vagabundean unos 100.000 perros en jaurías» (Pérez Monguió, 2005: 338). Aunque el problema no parezca ser de tal magnitud en España, el informe anual de 2019 de la Fundación Affinity, con los datos extraídos del Estudio sobre Abandono y Adopción de Animales de Compañía del año 2018, revela que 138.000 perros y gatos fueron recogidos por entidades protectoras durante 2018. El $91 \%$ de la calle. Estos datos sitúan a España como uno de los primeros países en la lista de abandono de perros y gatos. Se trata, por tanto, de un problema no teórico, sino real ${ }^{11}$, y de repercusiones obvias sobre la seguridad ciudadana ${ }^{12}$. Y es que, como explica Pérez Monguió, los animales abandonados «con el transcurso de los días se vuelven desconfiados y en algunos casos agresivos, provocando altercados con otros animales y con personas» (Pérez Monguió, 2005: 339). Estos altercados resultan cuantitativa y cualitativamente más graves en caso de que los animales abandonados sean potencialmente peligrosos ${ }^{13}$. Es en este tipo de abandono, por tanto, y no en otro, en el que debe centrarse el régimen sancionador de la LOPSC.

Por este motivo, creo que sería necesario modificar la letra del precepto o, al menos, realizar una interpretación correctora del mismo, en el sentido de que únicamente se sancionen en su virtud aquellos abandonos físicos que se produzcan en espacios públicos o privados de uso público o en condiciones que permitan al animal acceder a dichos espacios. Esto no resultaría ni siquiera incompatible con la literalidad del precepto, pues dichos abandonos siempre supondrán un peligro para la vida del animal. Por el contrario, las demás clases de abandonos (físicos en lugares estrictamente privados o asistenciales) no deberían ser subsumibles en el tipo del art. 37.16 LOPSC -independientemente de la interpretación que se hiciera del mismo- por no afectar a la seguridad ciudadana (ni a la moralidad pública).

\section{SU RELACIÓN CON EL DELITO DE ABANDONO DE ANIMALES DOMÉSTICOS PREVISTO EN EL ART. 337 BIS CP}

El art. 337 bis CP prevé como delito el abandono de un animal doméstico en condiciones en que pueda peligrar su vida o integridad. La diferencia fundamental que existe entre este precepto penal y el art. 37.16 LOPSC radica en el bien jurídico protegido por los mismos. Según la doctrina penalista, el bien jurídico protegido por el art. 337 bis CP es «primariamente el animal y de modo secundario, los intereses generales, encarnados, en este caso, en los sentimientos de piedad que la sociedad tiene frente a las situaciones que

10 Esto ni siquiera sería relevante a efectos de moralidad pública, pues la conducta no tendría trascendencia externa. Tal conducta sí que resultaría reprochable en el ámbito penal, donde el bien jurídico protegido son los propios animales domésticos y los intereses generales que se ven perjudicados con su abandono. Por eso, son numerosas las condenas a personas por abandonar animales en el interior de su vivienda. Vid., entre otras, la SAP de Barcelona n. ${ }^{\circ}$ 343/2019, de 24 de mayo (JUR\2019l209381) y la SAP de Valencia n. ${ }^{\circ} 24 / 2020$, de 20 de enero (JURI2020153723).

11 Y lo lleva siendo mucho tiempo (CASTRO ÁLVAREZ, 2019: 190-193). Es, por ello, que el Parlamento Europeo en su Resolución de 21 de enero de 1994, sobre el Bienestar y el Estatuto de los Animales, solicitó a los Estados miembros que aprobasen normas que previnieran el fenómeno del vagabundeo (PÉREZ MONGUIÓ, 2005: 338).

12 No solo sobre la seguridad ciudadana, sino, también, sobre la sanidad e higiene públicas, la seguridad vial e incluso el medio ambiente, pues el abandono de ciertas especies que en los últimos tiempos se han adquirido como mascotas puede causar desequilibrios ambientales. Es el problema relativo a las especies invasoras. En cualquier caso, como las repercusiones del abandono sobre todos estos ámbitos son tan perniciosas, para tratar de evitarlas, tradicionalmente los Ayuntamientos vienen gestionando, directa o indirectamente, el servicio público de recogida de animales abandonados.

13 Aunque si lo que se abandona es un animal potencialmente peligroso al autor del abandono se le puede sancionar bien por abandono, bien por dejar suelto un animal fiero o dañino. 
REALA. Nueva Época - N. 14, octubre 2020 - ISSN: 1989-8975 - DOI: https://doi.org/10.24965/reala.i14.10852 - [Págs. 104-120]

La infracción de abandono de animales domésticos en la Ley de seguridad ciudadana y en otras disposiciones penales y administrativas...

Carmen Martín Fernández

suponen maltrato o peligro para los animales domésticos» (Gómez Tomillo, 2015: 191). En el art. 37.16 LOPSC, como se estudió antes, el bien jurídico protegido es -o debe ser- la seguridad ciudadana, aunque con ello también puedan resultar tutelados de forma indirecta o refleja los propios animales o la moralidad pública que podría sufrir un perjuicio con su abandono. Precisamente, por ello, como luego explicaré, creo que no puede sostenerse que el art. 337 bis CP pueda solaparse o concurrir con el art. 37.16 LOPSC, pues son dos normas punitivas, una penal y otra administrativa sancionadora, con fundamentos totalmente distintos y que, por tanto, tipifican ilícitos diferentes.

Otra diferencia que, según creo, cabrá apreciar entre los dos preceptos, y que deriva de la anterior, consiste en que el abandono perseguido por el art. 337 bis CP será el que se produzca en condiciones peligrosas para la vida o la integridad del animal, siendo indiferente que sea un abandono físico o asistencial o que se produzca en espacios públicos o privados. Por eso, los Tribunales han condenado por el delito previsto en el actual art. 337 bis CP (y por la antigua falta del art. $631.2 \mathrm{CP}$ ) a los sujetos responsables de abandonar asistencialmente a animales en el interior de su vivienda ${ }^{14}$, pero no a los que, aun abandonándolos, no hayan puesto con ello en peligro su vida o integridad ${ }^{15}$.

\section{SU RELACIÓN CON LAS INFRACCIONES DE ABANDONO DE LAS LEYES AUTONÓMICAS DE PROTECCIÓN ANIMAL}

Todas las CC.AA han aprobado una Ley propia de protección animal. Se trata de normas que suelen establecer, entre otras cosas, prohibiciones de conductas que suponen maltrato, abandono o tenencia de animales sin reunir las condiciones higiénico-sanitarias que sean necesarias para garantizar su vida y salud, así como obligaciones censales, para que la Administración pueda controlar el número de animales domésticos existentes y la identificación de sus dueños ${ }^{16}$. Pero, además de prohibir el abandono de animales domésticos, todas esas Leyes, y esto es lo que importa a nuestros efectos, lo tipifican como una infracción administrativa ${ }^{17}$.

14 La SAP de Barcelona n. ${ }^{\circ}$ 343/2019, de 24 de mayo (JURI20191209381), confirmó la condena a la recurrente como autora criminalmente responsable del delito leve de abandono de animales domésticos del art. 337 bis CP. Y lo hizo porque constaba como hecho probado que abandonó su vivienda dejando en su interior a dos perros encerrados en el pasillo, los cuales fueron hallados en condiciones higiénicas lamentables, cubiertos de heces, desnutridos y con parásitos. La Audiencia consideró que la recurrente era criminalmente responsable por ser la propietaria de los perros y la persona que tenía la responsabilidad de atenderlos y no dejarlos en situación de abandono. De forma similar se ha pronunciado la SAP de Valencia n. ${ }^{\circ}$ 24/2020, de 20 de enero (JURI2020153723).

15 La SAP de Navarra n. ${ }^{\circ} 213 / 2018$, de 14 de septiembre (JURI20181315104), absolvió al recurrente del delito leve de abandono del art. 337 bis CP por no quedar probado que el abandono del burro hubiese puesto en peligro su vida o integridad física. Según la Audiencia Provincial, no resultó probado «que la omisión de la atención al mismo por parte del acusado constituyera un abandono que hubiese puesto en peligro su vida o integridad física». De forma parecida, la SAP de Lleida n. ${ }^{\circ}$ 97/2008, de 6 de marzo (JURI2008|143151), consideró que no podía condenarse a doña Dolores como autora de la falta del art. 631.2 CP por no resultar probado que con su conducta pusiera de forma objetiva en peligro la vida de los gatos que tenía en su casa, presuntamente abandonados y en condiciones poco higiénicas.

16 Son normas que provienen, en su mayoría, de ordenanzas municipales anteriores, por lo que han conseguido solucionar el problema de la dejadez de muchos Ayuntamientos (MUÑOZ MACHADO, 1999: 94-99).

17 El abandono está tipificado como infracción muy grave en el art. 38 b) de la Ley andaluza 11/2003, de 24 de noviembre, de protección de los animales; en el art. 28.4 d) de la Ley 5/1997, de 24 de abril, de protección de los animales de compañía de Castilla y León; en el art. 25.3 c) de la Ley 4/1994, de 8 de julio, de la Generalidad Valenciana, sobre protección de los animales de compañía; en el art. 24.3 d) de la Ley 8/1991, de 30 de abril, de protección de los animales de Canarias; en el art. 29 c) de la Ley 4/2016, de 22 de julio, de protección de los animales de compañía de la Comunidad de Madrid; en el art. 38.3 d) de la Ley 6/2017, de 8 de noviembre, de protección y defensa de los animales de compañía de la Región de Murcia; en el art. 26.3 e) de la Ley Foral 19/2019, de 4 de abril, de protección de los animales de compañía en Navarra; en el art. 27.3 b) de la Ley vasca 6/1993, de 29 de octubre, de protección de los animales; y en el art. 55.5) de la Ley 6/2018, de 26 de noviembre, de protección de los animales en la Comunidad Autónoma de La Rioja. Y como infracción grave en el art. 69.5) de la Ley 11/2003, de 19 de marzo, de protección animal en la Comunidad Autónoma de Aragón; en el art. 42 k) de la Ley asturiana 13/2002, de 23 de diciembre, de tenencia, protección y derechos de los animales; en el art. 47.4) de la Ley cántabra 3/1992, de 18 de marzo, de protección de los animales; en el art. 25.2 b) de la Ley $7 / 1990$, de 28 de diciembre, de protección de los animales domésticos de Castilla-La Mancha; en el art. 32.3 b) de la Ley 5/2002, de 23 de mayo, de protección de los animales en la Comunidad Autónoma de Extremadura; y en el art. $39 \mathrm{~g}$ ) de la Ley 4/2017, de 3 de octubre, de protección y bienestar de los animales de compañía en Galicia. Asimismo, es tipificado como infracción grave (art. 46.2 e) o muy grave (art. 46.3 a), según el abandono sea reiterado o no, masivo o individualizado, en la Ley 1/1992, de 8 de abril, de protección de los animales que viven en el entorno humano de las Islas Baleares; y como infracción grave (art. $44.3 \mathrm{v}$ ) o muy grave (art. $44.4 \mathrm{c}$ ), según si el abandono se realiza en condiciones que puedan conllevar riesgos o daños para el animal o no, en el Decreto Legislativo 2/2008, de 15 de abril, por el que se aprueba el Texto Refundido de la Ley de protección de los animales de Cataluña. 
REALA. Nueva Época - N. ${ }^{14}$, octubre 2020 - ISSN: 1989-8975 - DOI: https://doi.org/10.24965/reala.i14.10852 - [Págs. 104-120]

La infracción de abandono de animales domésticos en la Ley de seguridad ciudadana y en otras disposiciones penales y administrativas...

Carmen Martín Fernández

Las distintas CC.AA han ido aprobando esas Leyes esgrimiendo competencias sobre diferentes materias $^{18}$. Mayoritariamente se ha optado por fundamentar la aprobación de dichas leyes de protección animal en las competencias autonómicas en materia de agricultura y ganadería (art. 148.1.7. ${ }^{\text {a }} \mathrm{CE}$ ) y de medio ambiente (arts. 148.1.7. ${ }^{a}$ y 149.1.23. ${ }^{a} \mathrm{CE}$ ). Pero la finalidad de esas leyes no es otra que garantizar la protección y, en ciertos casos, el bienestar animal. Por este motivo, algunos Estatutos de Autonomía han incluido expresamente dentro de la competencia en agricultura y ganadería o vinculada a la misma la competencia en materia de protección y bienestar animal (es el caso de los EE.AA de Cataluña, Andalucía y Canarias) ${ }^{19}$. Lo cual es perfectamente posible pues la CE, a diferencia de la de otros países, no ha previsto expresamente una competencia estatal en materia de bienestar o protección animal ${ }^{20}$.

Precisamente, por esto, porque ya existen diecisiete leyes autonómicas de protección animal, creo que no tendría sentido alguno sostener que el objetivo del art. 37.16 LOPSC es tutelar a los animales. La diferencia principal que, por tanto, creo que debe predicarse entre ambos tipos de infracciones -del art. 37.16 LOPSC y de los tipos autonómicos- es la relativa al bien jurídico protegido: mientras que las leyes autonómicas de protección animal se encargan de proteger a los animales, la LOPSC se encarga de salvaguardar la seguridad ciudadana. Y, conforme a ello, las leyes autonómicas de protección animal deben castigar todo tipo de abandono en la medida en que pueda resultar perjudicial para la vida e integridad de los animales; mientras que la LOPSC debe ceñirse a castigar el abandono de animales domésticos con trascendencia para la seguridad ciudadana, es decir, aquel abandono físico que se produce en espacios públicos o privados de uso público o en condiciones que permiten al animal acceder a dichos lugares, el cual, además, también suele conllevar un peligro para los propios animales.

Por último, quisiera llamar la atención sobre dos similitudes que existen entre ambos ilícitos (la infracción del art. 37.16 LOPSC y las infracciones autonómicas de abandono animal). En primer lugar, que en ambos casos se trata de infracciones de peligro, por lo que ninguna de ellas requiere un resultado para entenderse consumadas: la infracción autonómica se consuma con el abandono que, de por sí, pone en peligro la integridad del animal, y la infracción de la LOPSC lo hace con el abandono en espacios públicos o privados de uso público, que, en sí mismo, conlleva un peligro para la seguridad ciudadana. No es necesario, por tanto, ni que el animal sufra daños efectivos (en el caso de la infracción autonómica) ni que las personas o bienes resulten lesionados por el vagabundeo del animal (en el supuesto de la infracción estatal) ${ }^{21}$. Y, en segundo lugar, que ambas infracciones pueden cometerse tanto con dolo como con culpa, pues así parece deducirse de los preceptos y así lo permite el art. 28.1 LRJSP. Precisamente, en esto último radica la diferencia entre estas infracciones y el delito de abandono del art. 337 bis CP, que solo admite la comisión dolosa ${ }^{22}$.

18 Por ejemplo, en el caso de Andalucía, el Preámbulo de la Ley 11/2003, de 24 de noviembre, de protección de los animales, alude a las competencias en sanidad e higiene, cultura, ocio y espectáculos. El Preámbulo de la Ley aragonesa se refiere, sin embargo, a las competencias autonómicas en ganadería, agricultura y medio ambiente. La Ley asturiana 13/2002, de 23 de diciembre, de tenencia, protección y derechos de los animales, por su parte, se dictó con base en la competencia en materia de ganadería y agricultura. La Ley balear 1/1992, de 8 de abril, de protección de los animales que viven en el entorno humano, alude a las competencias autonómicas en ganadería y promoción de la adecuada utilización del ocio. Y la Ley $4 / 2017$, de 3 de octubre, de protección y bienestar de los animales de compañía en Galicia, hace referencia exclusivamente a la competencia autonómica en materia medioambiental.

19 La Ley Orgánica 6/2006, de 19 de julio, de reforma del Estatuto de Autonomía de Cataluña, en su art. 116.1, atribuye a la Generalitat la competencia exclusiva en materia de agricultura y ganadería, la cual incluye la protección de los animales (apartado d). La Ley Orgánica 2/2007, de 19 de marzo, de reforma del Estatuto de Autonomía para Andalucía reconoce a la Comunidad Autónoma andaluza en su art. 48.1 la competencia exclusiva en materia de agricultura, ganadería y desarrollo rural, y en su art. 48.3 la competencia exclusiva en bienestar animal. Y la Ley Orgánica 1/2018, de 5 de noviembre, de reforma del Estatuto de Autonomía de Canarias prevé en su art. 130.1 que corresponde a la Comunidad Autónoma de Canarias la competencia exclusiva en materia de agricultura y ganadería, la cual incluye la protección y el bienestar de los animales (apartado e).

20 Como sí hace, por ejemplo, la Constitución alemana en su art. 74.1.20. En materia de protección animal la Federación tiene la competencia legislativa, en la medida que sea necesaria una regulación legislativa federal en interés de la totalidad del Estado para la creación de condiciones de vida equivalentes en el territorio federal o el mantenimiento de la unidad jurídica o económica (art. 72.2), teniendo los Länder la facultad de legislar sobre esta materia mientras y en la medida que la Federación no haya hecho uso mediante ley de su competencia legislativa (art. 72.1).

21 Este adelantamiento de las barreras de la protección y de la punibilidad es característico del Derecho Administrativo sancionador. La mayoría de las infracciones tipificadas son de peligro y para entenderlas cometidas y castigarlas no es necesario que se cause un daño real y efectivo, sino que basta con que se lleven a cabo conductas que sean peligrosas para determinados bienes jurídicos. En este sentido, Cano Campos explica que el Derecho Administrativo sancionador castiga «ilícitos que, en sí mismos y por sí sólo considerados, tienen baja intensidad, pero cuya multiplicación, desde una perspectiva sistémica, resultaría perturbadora para el éxito de determinados modelos o políticas sectoriales de intervención de los poderes públicos» (CANO CAMPOS, 2018: 18).

22 Como consecuencia de esta diferencia, y dado que el delito del art. 337 bis CP protege el mismo bien jurídico que los tipos de abandono de las leyes autonómicas de protección animal, es por lo que las conductas de abandono que se encuentran al límite entre el dolo eventual y la imprudencia, y que pueden resultar impunes penalmente si finalmente se consideran imprudentes, pueden ser 


\section{SU RELACIÓN CON LAS INFRACCIONES DE ABANDONO DE LAS ORDENANZAS DE CONVIVENCIA CIUDADANA Y DE PROTECCIÓN ANIMAL}

Muchos municipios han aprobado ordenanzas de convivencia ciudadana en las que a veces han tipificado como infracción el abandono de animales domésticos. En estos casos, podría pensarse que se hace así por las graves repercusiones que dicho ilícito puede provocar sobre la seguridad y la convivencia de los ciudadanos. Pero en ocasiones lo que la ordenanza verdaderamente protege al tipificar el abandono es el bienestar animal. Los dos ejemplos los tenemos en la ordenanza de medidas para fomentar y garantizar la convivencia ciudadana en el espacio público de Granada ${ }^{23}$. Su art. 151 tipifica como infracción «abandonar un animal potencialmente peligroso» y «dejar suelto un animal potencialmente peligroso o no haber adoptado las medidas necesarias para evitar su huida o su pérdida». Resulta claro que el precepto persigue, en este punto, garantizar la seguridad y convivencia ciudadanas. Pero también tipifica en otro apartado como infracción «abandonar animales, cuando el abandono se realice de manera que pueda causarles daños graves» y «mantener los animales sin la alimentación necesaria o en instalaciones inadecuadas desde el punto de vista higienicosanitario, de bienestar animal y de seguridad, cuando los riesgos para los animales sean muy graves». Con la previsión de estos ilícitos claramente se persigue proteger un bien distinto, que no es otro que el bienestar o la protección animal ${ }^{24}$.

Donde queda aún más claro que la única preocupación es la protección del animal es en las ordenanzas reguladoras de la tenencia de animales que tipifican como infracción el mero abandono de animales domésticos y no establecen ninguna condición adicional que haga pensar que lo relevante sea que el abandono se produzca en la vía pública o que el animal abandonado pueda causar desórdenes públicos ${ }^{25}$. La mayoría de los municipios cuenta con una ordenanza de este tipo ${ }^{26}$ (al igual que las CC.AA tienen una ley de protección animal). Y ello a pesar de que muchos de ellos también han aprobado una ordenanza reguladora de la convivencia ciudadana. Esto último parece confirmar que, en efecto, el bien jurídico protegido por los tipos de abandono de las ordenanzas reguladoras de la tenencia de animales es la protección animal y no la seguridad ciudadana, pues si no fuera así no se entiende por qué la infracción se tipifica en dichas ordenanzas y no en las de convivencia.

Sin embargo, excepcionalmente, algunas ordenanzas de protección animal tipifican ciertas infracciones con el claro objetivo de salvaguardar la seguridad ciudadana. Es el caso de la Ordenanza de Ávila sobre animales de compañía, que, aunque tipifica el abandono de animales en general (art. 81 b), también tipifica de forma específica el abandono de animales peligrosos (art. 77.1 a); lo que permite deducir que, mientras el primer precepto salvaguarda a los animales en sí mismos, el segundo trata de proteger la seguridad

castigadas en vía administrativa en virtud de dicha legislación autonómica. Es lo que debería ocurrir en los casos en que un sujeto deja a un animal encerrado en un vehículo al sol mientras se ausenta durante algunas horas, pues de un tiempo a esta parte la conducta se ha considerado impune penalmente por ser imprudente. Gómez Tomillo explica que dicha conducta no se ha venido considerando ni abandono ni maltrato porque ambos delitos exigen, como mínimo, dolo eventual (GÓMEZ TOMILLO, 2015: 185 y 195).

23 También en la Ordenanza de seguridad y convivencia ciudadana de Murcia, que tipifica, por una parte, una infracción de abandono de animales que parece preocuparse por la propia integridad de los animales (art. 134.5) y, por otra parte, una infracción de abandono de animales potencialmente peligrosos, que, por el contrario, parece salvaguardar la seguridad ciudadana (art. 136.1 a).

24 Lo mismo ocurre con la Ordenanza sobre protección de la convivencia ciudadana y prevención de las conductas antisociales de León, cuyo art. 23 h) tipifica como infracción grave «cualquier conducta de maltrato, menosprecio o trato degradante hacia los animales, especialmente de los de compañía» y con la Ordenanza municipal de medidas para el fomento y garantía de la convivencia ciudadana en los espacios públicos de Sevilla, que tipifica como infracción grave en su art. 40.3 b) el maltrato animal. El bien jurídico protegido en ambos preceptos parece ser el bienestar animal.

25 En el caso de Barcelona resulta aún más evidente que con la tipificación del abandono como infracción en la Ordenança sobre la protecció, la tinença i la venda d'animals se persigue proteger el bienestar animal, pues la gravedad de la infracción varía en función del riesgo en que se coloque al animal con el abandono.

26 Sin ánimo de exhaustividad, el art. 37 c) de la Ordenanza reguladora de la tenencia y protección de los animales de Madrid tipifica como infracción muy grave en su apartado 2 el abandono de cualquier animal. Lo mismo hace la Ordenanza municipal de Málaga de bienestar, protección y tenencia responsable de los animales en su art. 41.1.2. El art. 33.2 c) de la Ordenanza municipal de A Coruña para la protección y tenencia de animales tipifica como infracción grave el abandono de animales. La Ordenanza de Algeciras para la protección y tenencia de animales tipifica como infracción muy grave en su art. 59 el abandono de animales mediante remisión a la Ley andaluza de protección animal. La Ordenanza reguladora de la tenencia y protección de animales en el término municipal de Bilbao considera una infracción muy grave el abandono de un animal doméstico (art. 25.3 b). E igualmente hace la Ordenanza de Cáceres reguladora de la tenencia y circulación de animales en su art. 75.3 d). En el caso de Benalmádena, su Ordenanza de convivencia ciudadana tipifica algunas infracciones relacionadas con animales, pero la conducta concreta de abandono se tipifica como infracción muy grave en la ordenanza reguladora de protección, bienestar, tenencia responsable de animales y animales potencialmente peligrosos (art. 42.1). 
REALA. Nueva Época - N. ${ }^{14}$, octubre 2020 - ISSN: 1989-8975 - DOI: https://doi.org/10.24965/reala.i14.10852 - [Págs. 104-120]

ciudadana. También es el caso de las ordenanzas de Barcelona, de Benalmádena y de Cuenca ${ }^{27}$. Algunas ordenanzas reguladoras de la tenencia de animales incluso tipifican infracciones más propias de ordenanzas de convivencia ciudadana, pues tienen como objetivo, no la regulación de la tenencia de los animales y su protección, sino la conservación del espacio público y la garantía de la seguridad y la convivencia ciudadanas. Es lo que ocurre con la Ordenanza municipal sobre tenencia de animales de compañía, animales potencialmente peligrosos y sobre el servicio municipal de recogida de animales de Castellón, cuyo art. 60 A) tipifica como infracción leve en su primer apartado «no adoptar las medidas oportunas para impedir que los animales de compañía ensucien las vías o los espacios públicos». Obviamente, tiene sentido que esta infracción aparezca tipificada en una ordenanza municipal reguladora de la tenencia de animales, pero no por ello el bien jurídico protegido con la misma es necesariamente la protección animal. En este caso, como digo, es claramente la convivencia ciudadana y la higiene pública.

Lo que hay que concluir de este somero análisis de las ordenanzas municipales de convivencia ciudadana y de protección animal es que lo más importante no es en qué norma municipal se tipifica el abandono como infracción administrativa, sino la redacción del precepto concreto, que es la que determina cuál es el bien jurídico realmente protegido en cada caso. Si se tipifica, sin más, como infracción el abandono de animales domésticos, creo que habrá que concluir que el bien jurídico protegido es el bienestar o la protección animal. Pero si, por el contrario, se tipifica como infracción dejar sueltos o abandonar animales en condiciones de causar daños, entonces habrá que concluir que lo que se protege no es al animal en sí, sino la seguridad ciudadana. Precisamente por ello es por lo que defiendo que la infracción de abandono de animales domésticos del art. 37.16 LOPSC debería haberse redactado de otra forma.

\section{LA POSIBLE CONCURRENCIA DE NORMAS PUNITIVAS Y DE INFRACCIONES SOBRE ABANDONO DE ANIMALES DOMÉSTICOS}

\subsection{Distinción entre concursos de normas punitivas y de ilícitos}

La garantía non bis in idem prohíbe la imposición de dos castigos por un mismo hecho ${ }^{28}$. Pero, en realidad, no están prohibidos todos los casos de doble castigo. En verdad, lo que únicamente impide es que se impongan dos castigos por los mismos hechos, a la misma persona y con idéntico fundamento ${ }^{29}$. Lo refleja así el art. 31.1 LRJSP: «No podrán sancionarse los hechos que lo hayan sido penal o administrativamente, en los casos en que se aprecie identidad del sujeto, hecho y fundamento». Se requiere, por tanto, una triple identidad de sujeto, hecho y bien protegido por la norma.

La identidad de fundamento, explica Cano Campos, «alude a los bienes jurídicos implicados: si el hecho de un mismo sujeto lesiona o pone en peligro varios bienes jurídicos (o el mismo bien varias veces) no hay identidad de fundamento y, por tanto, cabe la duplicidad de sanciones» (Cano Campos, 2001: 195). Por lo que el autor manifiesta que la aplicación de la garantía non bis in idem no parte del hecho en sí, sino del ilícito, es decir, del hecho que lesiona o pone en peligro un bien jurídico. De modo que lo que se impide con ella es que se castigue a un sujeto dos veces por una única vulneración del ordenamiento jurídico. Con independencia de que los castigos aplicables sean penales, administrativos o uno penal y otro administrativo. Es, por ello, que esta garantía constitucional únicamente resulta aplicable en los casos de concurrencia de normas, pero no en los de concurso de infracciones. Veamos con un poco de más detenimiento en qué se diferencian ambas categorías de concursos.

El concurso de normas punitivas se produce cuando un determinado comportamiento realiza el supuesto de hecho de dos o más normas sancionadoras, o lo que es lo mismo, cuando dos o más normas sancio-

27 La Ordenança sobre la protecció, la tinença i la venda d'animals de Barcelona tipifica como infracción, por una parte, el abandono de animales (51.2 b y 51.3 r) y, por otra parte, el abandono de animales peligrosos (art. 53.2 a); la ordenanza municipal de Benalmádena reguladora de la protección, el bienestar y la tenencia responsable de animales tipifica como infracción el abandono de animales (art. 42.1) y dejar sueltos animales peligrosos (art. 42.2); y la ordenanza municipal de medio ambiente de Cuenca tipifica como infracción en su art. 294 el abandono de animales, en su art. 312 abandonar un animal potencialmente peligroso y en su art. 313 dejar suelto a un animal potencialmente peligroso.

28 La garantía non bis in idem no aparece consagrada expresamente en la Constitución, pero el TC la considera implícita en el art. 25.1 CE por la estrecha vinculación que guarda con el principio de legalidad punitiva y, en especial, con el de tipicidad allí consagrados (ALARCÓN SOTOMAYOR, 2010a: 390-391).

29 Alarcón Sotomayor explica que «La garantía non bis in idem impide sancionar aquello que sea igual a lo ya sancionado previamente; y "lo igual" o "lo mismo" existe cuando se da la referida triple identidad» (ALARCÓN SOTOMAYOR, 2008: 41). 
REALA. Nueva Época - N. ${ }^{14}$, octubre 2020 - ISSN: 1989-8975 - DOI: https://doi.org/10.24965/reala.i14.10852 - [Págs. 104-120]

La infracción de abandono de animales domésticos en la Ley de seguridad ciudadana y en otras disposiciones penales y administrativas...

Carmen Martín Fernández

nadoras tipifican el mismo ilícito ${ }^{30}$. La doctrina se refiere a este concurso como aparente y no real porque «finalmente sólo una de las normas podrá aplicarse en el caso concreto» (Alarcón Sotomayor, 2008: 54). Puesto que, como digo, es en estos supuestos donde entra en juego la garantía non bis in idem, que exige elegir una única norma aplicable, pues dicha norma ya absorbe todo el desvalor del hecho contemplado por la otra y si se aplicaran todas las normas sancionadoras «lo que es único sería tratado y castigado como plural» (Cano Campos, 2018: 136). Para elegir la norma aplicable en cada caso, habrá que proceder de la siguiente manera:

- Si una norma es penal y otra es administrativa, prevalece la norma penal. Esta solución, según ha manifestado el TC, la impone la propia CE en su art. 25, del que se deduce la subordinación de la potestad sancionadora de la Administración a la autoridad judicial dada la competencia exclusiva de la jurisdicción penal en el conocimiento de los hechos constitutivos de infracción penal (Alarcón Sotomayor 2010b: 395-396; Alarcón Sotomayor, 2008: 89-90). Por eso, si durante la tramitación de un procedimiento sancionador, la Administración sospecha que la conducta constitutiva de infracción administrativa puede ser también delito, debe suspender el procedimiento, comunicar el hecho a las autoridades judiciales y esperar la sentencia penal ${ }^{31}$. Así lo declara en el sector específico de la seguridad ciudadana el art. 45.2 LOPSC $^{32}$. Si la sentencia condena el hecho, la Administración ya no puede hacer nada. Pero si la sentencia declara que el hecho no es constitutivo de delito, entonces la Administración podrá, en ciertos casos y respetando siempre la declaración de hechos probados de la sentencia penal (art. 77.4 LPAC), continuar la tramitación del procedimiento e imponer la sanción que corresponda. Esto último también lo prevé la LOPSC en su art. $45.3^{33}$.

- Si las dos normas sancionadoras son administrativas, como no existe ninguna regla en la LRJSP que establezca cuál es la prevalente con carácter general, la doctrina ha propuesto seguir las reglas del art. 8 CP (Nieto García, 2005: 517; Rebollo Puig e Izquierdo Carrasco, 2005: 632; Cano Campos, 2018: 138; Alarcón Sotomayor, 2008: 84-85). Lo mismo ha sugerido en ocasiones la jurisprudencia ${ }^{34}$. Algunas leyes sectoriales han establecido estas reglas expresamente. Lo ha hecho, por ejemplo, el art. 31.1 LOPSC que, en caso de concurrencia de normas administrativas sancionadoras (dos de la propia LOPSC o de la LOPSC y de otra ley diferente) ha declarado aplicables la regla de la especialidad, en su defecto, la regla de la consunción y, finalmente, la regla in dubio pro gravissima poena. Estas reglas son las mismas que recoge el art. $8 \mathrm{CP}$.

Por lo que se refiere al concurso de infracciones, puede tener lugar en varios casos. El más común es cuando con varios hechos se cometen varios ilícitos distintos (concurso real). Pero también se produce cuando una infracción es medio para cometer otra diferente (concurso medial) y cuando con un mismo hecho se cometen varios ilícitos porque se vulnera varias veces el mismo o distinto bien jurídico (concurso ideal) ${ }^{35}$. En ninguno de estos casos resulta de aplicación la garantía non bis in idem, pues no concurre la triple identidad de sujeto, hecho y fundamento (Alarcón Sotomayor, 2010b: 374). Antes, al contrario, en todos ellos, al aplicar varias normas sancionadoras «no hay un tratamiento plural de lo que es único, sino un tratamiento plural de lo vario o desigual» (Cano Campos, 2018: 139). En ocasiones, se tratará de hechos diferentes (concurso real) y en otras ocasiones el mismo hecho lesionará o pondrá en peligro diferentes bienes jurídicos (concurso ideal

30 El Diccionario Panhispánico del Español Jurídico define el concurso de normas punitivas como la situación que acontece cuando dos normas (penales, administrativas o una penal y otra administrativa) tipifican el mismo ilícito o ilícitos similares, pero de modo que el previsto por una de ellas absorbe o consume completamente el desvalor del contemplado por la otra. Disponible en versión electrónica en: https://dej.rae.es/.

31 Esta necesidad de suspensión del procedimiento administrativo sancionador ha sido incluso calificada en alguna ocasión como principio general del Derecho por el Tribunal Supremo (STS de 23 de enero de 2004, RJ 2004I563).

32 Art. 45.2 LOPSC: «En los supuestos en que las conductas pudieran ser constitutivas de delito, el órgano administrativo pasará el tanto de culpa a la autoridad judicial o al Ministerio Fiscal y se abstendrá de seguir el procedimiento sancionador mientras la autoridad judicial no dicte sentencia firme o resolución que de otro modo ponga fin al procedimiento penal, o el Ministerio Fiscal no acuerde la improcedencia de iniciar o proseguir las actuaciones en vía penal, quedando hasta entonces interrumpido el plazo de prescripción. La autoridad judicial y el Ministerio Fiscal comunicarán al órgano administrativo la resolución o acuerdo que hubieran adoptado».

33 Art. 45.3 LOPSC: «De no haberse estimado la existencia de ilícito penal, o en el caso de haberse dictado resolución de otro tipo que ponga fin al procedimiento penal, podrá iniciarse o proseguir el procedimiento sancionador. En todo caso, el órgano administrativo quedará vinculado por los hechos declarados probados en vía judicial».

34 Vid. entre otras, la STS de 8 de marzo de 2002 (RJ 2002/3406) y la STS de 1 de junio de 2000 (RJ 200017058 )

35 El Diccionario Panhispánico del Español Jurídico define el concurso de infracciones como la concurrencia de dos o más ilícitos diferentes, penales, administrativos o penales y administrativos. Disponible en versión electrónica en: https://dej.rae.es/. 
REALA. Nueva Época - N. ${ }^{14}$, octubre 2020 - ISSN: 1989-8975 - DOI: https://doi.org/10.24965/reala.i14.10852 - [Págs. 104-120]

La infracción de abandono de animales domésticos en la Ley de seguridad ciudadana y en otras disposiciones penales y administrativas...

Carmen Martín Fernández

y concurso medial). En el Derecho Penal, en el caso del concurso real lo que procede es imponer los castigos que correspondan en función de los delitos cometidos (art. $73 \mathrm{CP}$ ); mientras que en el concurso medial y en el concurso ideal procede aplicar la pena prevista para el delito más grave en su mitad superior, sin que la misma pueda superar la pena que correspondería si los delitos se hubieran castigado de forma separada (art. 77 CP). Sin embargo, en el Derecho Administrativo sancionador no existe una regulación general y completa de los concursos de infracciones. El art. 29 LRSJP solo contempla la regla a aplicar en el concurso medial (imposición de la sanción correspondiente a la infracción más grave cometida), pero no establece cómo proceder en caso de concurso real o ideal, por lo que podrían aplicarse analógicamente las reglas del $\mathrm{CP}$, salvo que una ley sectorial dispusiera otra cosa. Por lo que respecta a la LOPSC, sí ha abordado la regulación de los concursos de infracciones, pero lo ha hecho de forma incompleta pues solo ofrece una solución para los concursos ideal y medial en su art. 31.2: «En el caso de que un solo hecho constituya dos o más infracciones, o cuando una de ellas sea medio necesario para cometer la otra, la conducta será sancionada por aquella infracción que aplique una mayor sanción» ${ }^{36}$. Como vemos, prevé una regla parecida a la prevista en el art. 77 $\mathrm{CP}$, pero no idéntica, pues, por una parte, exige aplicar la infracción que conlleve una mayor sanción en lugar de la sanción prevista para la infracción más grave; y, por otra parte, no exige que la sanción se imponga en su mitad superior. A pesar de ello, puede llegarse a la misma solución: en primer lugar, porque en casi todos los casos la infracción que conlleve una mayor sanción será la infracción más grave (al menos cuando las sanciones que se comparan son de la misma ley); $y$, en segundo lugar, porque a través del juicio de reprochabilidad, la Administración debe tener en cuenta como criterio de agravación de la sanción a imponer que una de las infracciones va a quedar impune (Izquierdo Carrasco, 2001: 234) ${ }^{37}$.

En cualquier caso, lo que debe tenerse en cuenta es que estas reglas aplicables a los concursos de infracciones no se basan en el principio non bis in idem, sino que han sido previstas por el legislador -en el $\mathrm{CP}$ o en normas administrativas sancionadoras- para «suavizar o dulcificar esa regla general en los casos en que la simple suma aritmética de todos los castigos procedentes entrañe un mal desproporcionado, por excesivo, a la gravedad real de la conducta infractora apreciada en su conjunto» (Alarcón Sotomayor, 2008: 30-31) y, por tanto, con fundamento en el principio de proporcionalidad.

Explicado todo lo anterior, procede analizar el art. 37.16 LOPSC y su posible concurrencia con el art. 337 bis CP y los preceptos que tipifican el abandono en las leyes autonómicas de protección animal y en las ordenanzas de convivencia ciudadana o de protección animal. En estos casos, ¿se producen concursos de normas o de infracciones? ¿Qué solución procede en cada caso? Trataré de dar respuesta en los siguientes epígrafes.

\subsection{El art. 37.16 LOPSC y el art. 337 bis CP}

Dada la literalidad del art. 37.16 LOPSC, que en este punto -como en muchos otros- lo que ha hecho ha sido reproducir la antigua falta del art. $631.2 \mathrm{CP}$, sin percatarse de que quizás una ley de seguridad ciudadana no debiera tener tal formulación (por todo lo que anteriormente he explicado), cierto sector de la doctrina considera que tanto este precepto de la LOPSC como el art. 337 bis CP protegen el mismo bien jurídico, pues ambos parecen proteger a los propios animales y su bienestar y a los intereses generales que se ven perjudicados en caso de abandono. Y, conforme a ello, afirma que se produce un concurso de normas punitivas y que resultará de aplicación una u otra en función de la gravedad de la conducta ${ }^{38}$, pues

36 La LOPSC/92, a diferencia de la LOPSC actual, establecía como regla que la imposición de una pena excluía en todo caso la sanción administrativa, sin exigir que hubiera identidad de sujeto, hecho y fundamento. Su art. 32.1 era tajante al respecto: «No se podrán imponer sanciones penales y administrativas por unos mismos hechos». De ese modo, se excluía la sanción administrativa no solo cuando se producía un concurso de normas penal y administrativa sancionadora sino, también, cuando se producía un concurso de delito e infracción. La LOPSC actual, por el contrario, exige la triple identidad para que una pena excluya una sanción administrativa. Y lo hace afirmando en su art. 45.1 que «No podrán sancionarse los hechos que hayan sido sancionados penal o administrativamente cuando se aprecie identidad de sujeto, de hecho y de fundamento». Esta última regla es más coherente, pues la que establecía la LOPSC/92 y todavía establecen algunas leyes sectoriales conlleva que «algunas conductas merecedoras de un castigo en vía administrativa queden parcialmente impunes por haber recaído sobre ellas una pena judicial que, sin embargo, no ha agotado todo el reproche que merecen» (ALARCÓN SOTOMAYOR, 2010a: 406).

37 Aunque realmente, podría sostenerse, como hace Alarcón Sotomayor, que «esas reglas especiales [aplicables a los concursos de infracciones] no suponen que no se sancione cada una de las infracciones en concurso, sino solo que se castiguen de una forma más suave por entender que así se conseguirá un castigo más proporcionado» (ALARCÓN SOTOMAYOR, 2010a: 404).

38 En este sentido se han pronunciado algunos penalistas, como Blanco Cordero, que cree conveniente «entender que cuando el riesgo sea leve o menos grave, la conducta debe ser considerada una infracción administrativa, y reservar exclusivamente para el delito los riesgos graves para la vida o la integridad del animal (ultima ratio)» (GÓMEZ TOMILLO, 2015: 190). Parece, por tanto, que Blanco 
REALA. Nueva Época - N. 14, octubre 2020 - ISSN: 1989-8975 - DOI: https://doi.org/10.24965/reala.i14.10852 - [Págs. 104-120]

La infracción de abandono de animales domésticos en la Ley de seguridad ciudadana y en otras disposiciones penales y administrativas...

Carmen Martín Fernández

la aplicación simultánea de ambas vulneraría la garantía non bis in idem. Siguiendo a esta doctrina, y dada la regla de la preferencia de la vía penal, si la Administración sospechara que la conducta constitutiva de infracción administrativa también podría ser constitutiva de delito, debería suspender el procedimiento administrativo sancionador o no iniciarlo y pasar el tanto de culpa a la autoridad judicial para que decidiera al respecto (art. 45.2 LOPSC), pues de lo contrario, si siguiera adelante y llegara a sancionar podría vulnerar la garantía non bis in idem y, con ello, un derecho fundamental del inculpado ${ }^{39}$. Solo en el caso de una sentencia absolutoria -que no declarase la inexistencia de los hechos o la falta de participación del sujeto- podría la Administración continuar o iniciar el procedimiento sancionador con posterioridad (art. 45.3 LOPSC).

Sin embargo, como vengo defendiendo, creo que podría sostenerse que el bien jurídico protegido por el art. 37.16 LOPSC es otro. A mi modo de ver, lo más correcto sería considerar que el precepto de la LOPSC, a pesar de su literalidad, salvaguarda la seguridad ciudadana -por el peligro que para ella supone el abandono de animales y su posterior vagabundeo- y que el precepto penal protege al animal y su integridad y a los intereses generales que se ven perjudicados ante su abandono. Conforme a esta tesis, ambos preceptos tipificarían ilícitos distintos, por lo que no se produciría un concurso de normas, sino un concurso de infracciones; en concreto, podría tratarse de un concurso ideal. Como consecuencia, la garantía non bis in idem no entraría en juego y no resultaría imposible aplicar ambos preceptos de forma simultánea para castigar al sujeto que abandona a un animal doméstico en condiciones en que pueda peligrar su vida o integridad y poniendo con ello en riesgo la seguridad ciudadana ${ }^{40}$. Pero quizás lo procedente sería suavizar la regla de acumulación de castigos de alguna manera. Sin embargo, el legislador no ha previsto ninguna matización a dicha regla para los supuestos en que concurra un delito y una infracción administrativa. ¿Sería posible aplicar el art. 77.2 CP o el art. 31.2 LOPSC para ello? No tengo claro que las soluciones previstas en dichos preceptos sean aplicables a un concurso de delito e infracción. Claramente la regla prevista en el art. $77.2 \mathrm{CP}$ es aplicable solo a los concursos de delitos. Y seguramente la regla del art. 31.2 LOPSC solo resulte de aplicación respecto a los concursos de infracciones administrativas de la propia LOPSC (ni siquiera parece aplicable a los concursos de infracciones de la LOPSC y de otra ley, tal y como ocurre con el art. 31.1 LOPSC, que se declara aplicable a los concursos de normas de la propia LOPSC o de la LOPSC y de otra ley distinta). Pero si pudiera utilizarse la solución del art. 77.2 CP (imposición de la pena prevista para la infracción más grave en su mitad superior), surgirían dos problemas. El primero es el de la comparación de ilícitos que son heterogéneos (delito e infracción administrativa). Aunque en este caso concreto puede solucionarse fácilmente pues parece que claramente es más grave el ilícito penal (delito leve) que el ilícito administrativo (infracción leve). El segundo problema es el relativo a la competencia para castigar, pues si finalmente puede concluirse que una de las infracciones es más grave que la otra, uno de los órganos debe abstenerse de ejercer la potestad sancionadora y remitir el expediente a aquel que es competente para aplicar la norma que prevé la infracción más grave. Como consecuencia, lo que procede en este caso es que la Administración suspenda o no incoe el procedimiento administrativo sancionador hasta que se pronuncie la autoridad judicial, pues «la jurisprudencia más reciente viene declarando que el deber de no tramitar el procedimiento administrativo sancionador nace aun cuando no se trate ni del mismo sujeto ni del mismo fundamento jurídico, con tal de que concurra el mismo hecho» (Alarcón Sotomayor, 2010b: 401). Esta aparente contradicción es justificada por la doctrina, que explica que lo que esto pone de manifiesto es que el deber de no tramitar el procedimiento sancionador no es tanto un instrumento para garantizar el non bis in idem material, sino para asegurar la vinculación de la Administración a los hechos declarados probados por la sentencia penal en el procedimiento sancionador ulterior (Alarcón Sotomayor, 2010b: 403; Alarcón Sotomayor, 2008: 100)ㄴ․

Cordero considera idéntico el fundamento del art. 37.16 LOPSC y el del art. 337 bis CP. Aunque otros, como Vercher Noguera, creo que de forma equivocada, directamente sugieren que esta doble regulación constituye un error y concluyen que «la conducta controvertida debe ser de orden penal y no administrativo» (DEL MORAL GARCÍA Y ESCOBAR JIMÉNEZ, 2018: 2.107).

39 Y ello porque la jurisprudencia del TC, que considera implícita la garantía non bis in idem en el art. 25.1 CE, «ha convertido al non bis in idem material (a la prohibición de doble sanción por la misma infracción) en un derecho fundamental del acusado» (ALARCÓN SOTOMAYOR, 2010a: 395).

40 Cano Campos pone de manifiesto que cierto sector doctrinal ha vinculado el principio non bis in idem al concurso de infracciones «cuando lo cierto es que dicha modalidad concursal, a diferencia del concurso de normas, nada tiene que ver con el principio en cuestión, pues cuando estamos en presencia de un concurso de infracciones no se cumplen todos los requisitos que habitualmente se exigen al non bis in idem: o falta la identidad de hecho, porque hay una pluralidad de ellos (concurso real), o falta la identidad de fundamento, porque un solo hecho lesiona o pone en peligro varios bienes jurídicos (concurso ideal)» (CANO CAMPOS, 2001: 193).

41 Por eso, Alarcón Sotomayor afirma más adelante que «el deber de paralizar el procedimiento administrativo sancionador nace en los casos en los que exista la triple identidad y, también, en muchos otros en que no existe» (ALARCÓN SOTOMAYOR, 2008: 115), pues lo que pretende garantizarse con ello no es otra cosa que la sujeción de la autoridad administrativa a los hechos declarados 
REALA. Nueva Época - N. ${ }^{14}$, octubre 2020 - ISSN: 1989-8975 - DOI: https://doi.org/10.24965/reala.i14.10852 - [Págs. 104-120]

Para evitar problemas, Cano Campos sugiere la siguiente solución: «admitir la imposición de las dos sanciones correspondientes a las infracciones cometidas, pero de forma atenuada» (Cano Campos, 2001: 247). De este modo no habría necesidad de comparar los ilícitos para determinar el más grave ni se plantearían problemas competenciales algunos, pues cada órgano ejercería la potestad sancionadora respecto de la infracción para la que es competente. Desde luego, esta propuesta lege ferenda plantearía muchos menos problemas que los que surgen con la aplicación, aunque sea analógica, de la solución del art. 77.2 CP.

En definitiva, en mi opinión, el art. 37.16 LOPSC y el art. 337 bis CP tipifican ilícitos por completo distintos $y$, por tanto, no resulta de aplicación uno u otro precepto en función de la gravedad de la conducta, sino que el precepto de la LOPSC será aplicable cuando el abandono de un animal doméstico ponga en peligro la seguridad ciudadana y el art. 337 bis CP resultará de aplicación cuando el abandono de un animal doméstico suponga un riesgo para la vida o integridad del $\mathrm{mismo}^{42}$. Lo que ocurre es que la aplicación de un precepto no excluye la del otro (por tener fundamentos totalmente distintos), por lo que al sujeto que abandona a un animal doméstico poniendo con ello en riesgo tanto al animal como a la seguridad ciudadana se le podrán imponer ambos castigos, sin vulneración alguna de la garantía non bis in idem, aunque quizás habría que suavizar la regla de la acumulación de castigos en virtud del principio de proporcionalidad.

Solo si se partiera de la base de que el fundamento de ambas normas es el mismo (la protección animal, que en el caso del precepto de la LOPSC más bien sería la más amplia moralidad pública, elemento constitutivo del orden público) habría que emprender un análisis jurídico para decidir qué consecuencia punitiva procedería imponer para evitar vulneraciones del principio non bis in idem. En estos casos, como el concurso se produciría entre una norma penal y otra administrativa sancionadora, prevalecería la norma penal. De cualquier forma, esta concurrencia, y posible inaplicación del art. 37.16 LOPSC o del art. 337 bis CP, se solventaría si la infracción, en lugar de su redacción actual, asumiera la que propuse más arriba. Pues así resultaría indudable que el fundamento de ambas normas sería distinto.

Pues bien, llegados a este punto, y habiendo reconocido no ser partidaria de esta última tesis, sino de considerar compatibles tanto la sanción derivada del art. 37.16 LOPSC como la pena impuesta por la comisión del delito de abandono del art. 337 bis CP por proteger ambas normas bienes jurídicos diversos, he de admitir que no ocurre lo mismo con relación a las infracciones de abandono que tipifican las leyes autonómicas de protección animal. Estas normas sí que tienen el mismo fundamento que el precepto penal. Por lo que, entre estas y el art. 337 bis CP sí surge un concurso de normas punitivas y, por tanto, sí que habría que llevar a cabo la operación de análisis en cada caso concreto para determinar si la conducta es merecedora de reproche penal o de represión administrativa. Entonces sí, la Administración autonómica que pretenda castigar a un sujeto por haber abandonado a un animal en virtud de su normativa protectora de animales, si considera que el hecho es de tal gravedad que puede ser constitutivo de delito, tendrá que suspender el procedimiento administrativo sancionador y esperar a que un Juez se pronuncie al respecto. Solo si en sede penal no se aprecia delito podrá proseguir la Administración con la tramitación del procedimiento y, en su caso, sancionar al sujeto. A mi parecer, solo aquellas conductas dolosas más graves y que supongan un peligro concreto para la vida del animal deberán ser castigadas en sede penal, mientras que las demás conductas dolosas menos graves y que supongan un peligro abstracto, así como todas las imprudentes, deberán ser reprimidas en vía administrativa.

\subsection{El art. 37.16 LOPSC y las infracciones de abandono de la normativa autonómica}

Como vengo defendiendo, el fundamento del art. 37.16 LOPSC es proteger la seguridad ciudadana, mientras que el de las normas autonómicas de protección animal es el mismo que el del art. 337 bis CP, es decir, proteger a los animales en sí mismos y su bienestar. Siguiendo este planteamiento, de nuevo nos

probados en la sentencia penal. Un aspecto práctico muy importante y relacionado con esto es el que pone de manifiesto la autora: «en todos estos casos debe entenderse que las actuaciones penales interrumpen la prescripción de la infracción administrativa y suspenden los plazos de duración máxima del procedimiento sancionador a efectos de su caducidad» (pág. 132).

42 Lo mismo ocurre con relación al art. $337 \mathrm{CP}$, que tipifica como delito el maltrato animal, pues su bien jurídico protegido es el mismo que el del art. 337 bis CP. Además, la doctrina considera que el delito de maltrato puede cometerse mediante omisión, a través del abandono que conlleva como resultado la muerte o lesiones en el animal (DEL MORAL GARCÍA Y ESCOBAR JIMÉNEZ, 2018: 2.104-2.105; GÓMEZ TOMILLO, 2015: 181 y 189; MESÍAS RODRÍGUEZ, 2018: 87). En estos casos, como el art. 37.16 LOPSC y el art. $337 \mathrm{CP}$ también tienen distintos fundamentos, si el abandono provoca la muerte o lesiones en el animal (abandono constitutivo de maltrato) y además ha supuesto un peligro para la seguridad ciudadana, es posible, conforme a mi tesis, imponer al sujeto que lo llevó a cabo tanto la sanción de la LOPSC como la pena del art. 337 CP (aunque quizás proceda matizar la regla de la acumulación de castigos conforme a lo explicado con anterioridad). 
REALA. Nueva Época - N. 14, octubre 2020 - ISSN: 1989-8975 - DOI: https://doi.org/10.24965/reala.i14.10852 - [Págs. 104-120]

La infracción de abandono de animales domésticos en la Ley de seguridad ciudadana y en otras disposiciones penales y administrativas...

encontraríamos ante dos preceptos que tipifican ilícitos distintos, por lo que no habría que aplicar la garantía non bis in idem, que únicamente entra en juego para evitar los casos de doble castigo cuando se produce la triple identidad de sujeto, hecho y fundamento. Al contrario, si la conducta de abandono realizada por el sujeto encajara tanto en el art. 37.16 LOPSC como en el precepto de la ley autonómica correspondiente, se produciría un concurso de infracciones administrativas, posiblemente de carácter ideal. No existe una regla legal aplicable a estos casos (el art. 77.2 CP es aplicable a los concursos de delitos y el art. 31.2 LOPSC a los concursos de infracciones de la LOPSC) por lo que a priori correspondería aplicar ambos preceptos e imponer las dos sanciones administrativas. Si ello se considerase excesivo o desproporcionado, creo que una posible solución pasaría por aplicar analógicamente las reglas del art. 77.2 CP (imposición de la sanción prevista para la infracción más grave en su mitad superior). Aunque, reitero, creo que lo más adecuado sería, siguiendo a Cano Campos, que legalmente se admitiera la imposición de las dos sanciones correspondientes a las infracciones cometidas, pero de forma atenuada (Cano Campos, 2001: 247), pues así se evitan los problemas derivados del ejercicio de la potestad sancionadora por órganos diferentes (en este caso, Administración estatal y Administración autonómica).

Solo si se partiera de la base de que el bien jurídico protegido por el art. 37.16 LOPSC es el mismo que el salvaguardado en los preceptos autonómicos, habría que respetar el principio non bis in idem y decidir la norma administrativa sancionadora aplicable. En este caso, parece que la solución la ofrece el art. 31.1 LOPSC, que, como he explicado, se declara aplicable a los concursos de normas, no solo de la propia LOPSC, sino también de la LOPSC y de otra ley distinta (con todo lo cuestionable que hay en ello). En este supuesto, quizás la mejor solución sería sancionar al sujeto en virtud de la normativa autonómica por ser la ley especial preferente a la general (art. 31.1 a LOPSC). Eso sí, solo después de haber descartado la aplicación del art. 337 bis $\mathrm{CP}$, de idéntico fundamento, dada la prevalencia de la norma penal.

\subsection{El art. 37.16 LOPSC y las infracciones de abandono de las ordenanzas de convivencia ciudadana y de protección animal}

Unos epígrafes más arriba he expuesto cómo las ordenanzas municipales, tanto de convivencia ciudadana como de protección animal, suelen tipificar como infracción tanto el abandono de animales domésticos para tratar de protegerlos, como dejarlos sueltos o abandonarlos cuando sean peligrosos o dañinos.

Llegados a este punto, lo relevante es destacar que los preceptos de dichas ordenanzas solo resultarán de aplicación en defecto de ley. Y ello porque, como explica Alarcón Sotomayor, no se trata de concursos de normas de un mismo ordenamiento, sino de relaciones entre ordenamientos jurídicos distintos, por lo que «puede entenderse que todas las normas tipificadoras que contengan las ordenanzas son, en realidad, solo de aplicación subsidiaria: solo son aplicables si la conducta no está prevista y sancionada en una norma estatal o autonómica» (Alarcón Sotomayor, 2019b: 297) ${ }^{43}$. Dicha regla se encuentra incluso positivizada en el art. 140.1 a) de la Ley $7 / 1985$, de 2 de abril, Reguladora de las Bases del Régimen Local, para aquellos casos en que el concurso de normas se produce entre los preceptos de las ordenanzas municipales y las normas sancionadoras de la LOPSC, pues el precepto establece que serán muy graves las infracciones que supongan una perturbación relevante de la convivencia ciudadana siempre que se trate de conductas no subsumibles en los tipos previstos en la Ley de Seguridad Ciudadana ${ }^{44}$.

Como consecuencia, y dada la redacción del art. 337 bis CP, del art. 37.16 LOPSC y de los preceptos que tipifican el abandono como infracción en las leyes autonómicas de protección animal, difícilmente puede imaginarse un escenario en el que resulten aplicables las normas de ámbito municipal.

43 Y ello porque la tipificación realizada mediante ordenanzas locales no puede suponer una alteración de la regulación de las leyes estatales o autonómicas que tipifiquen infracciones y prevean sus correspondientes sanciones, ni puede impedir su aplicación ni desplazarlas (REBOLLO PUIG et al., 2007: 3.745-3.749). Los autores explican que puede considerarse contraria a la ley «la norma sancionadora local que exactamente para un mismo supuesto de hecho establezca una sanción distinta a la prevista en la legislación estatal o autonómica» (pág. 3.746). Y añaden que incluso puede afirmarse que, si la ordenanza tipifica las conductas ya tipificadas en las leyes estatales y autonómicas, está desbordando la autorización de los arts. 139 a 141 de la LRBRL, pues dichos preceptos admiten la tipificación de infracciones mediante ordenanzas «en defecto de normativa sectorial específica» y habilitan a los municipios a sancionar «salvo previsión legal distinta».

44 Art. 140.1 LRBRL: «(...) Serán muy graves las infracciones que supongan: a) Una perturbación relevante de la convivencia que afecte de manera grave, inmediata y directa a la tranquilidad o al ejercicio de derechos legítimos de otras personas, al normal desarrollo de actividades de toda clase conformes con la normativa aplicable o a la salubridad u ornato públicos, siempre que se trate de conductas no subsumibles en los tipos previstos en el capítulo IV de la Ley 1/1992, de 21 de febrero, de Protección de la Seguridad Ciudadana (...)». Remisión esta última que debe entenderse realizada en la actualidad al Capítulo V de la LOPSC. 
REALA. Nueva Época - N. 14, octubre 2020 - ISSN: 1989-8975 - DOI: https://doi.org/10.24965/reala.i14.10852 - [Págs. 104-120]

\section{CONCLUSIONES}

Del estudio de la infracción leve relativa al abandono de animales domésticos tipificada por el art. 37.16 LOPSC se extrae como conclusión principal que la técnica legislativa consistente en transformar automáticamente antiguas faltas del Código Penal en infracciones administrativas puede conllevar el surgimiento de múltiples problemas. En este caso, para evitar tener que cuadrar el círculo, como se hace en este trabajo, lo ideal sería que el precepto se modificara de tal forma que quedase claro que el bien jurídico protegido es la seguridad ciudadana. Solo así se evitarían concursos de normas sancionadoras innecesarios y se conseguiría castigar una conducta reprochable que, de otro modo, resultaría impune. Pues si se optara por la tesis contraria y se mantuviera que este precepto protege a los animales (lo cual parece posible dada su redacción actual), los abandonos que no conlleven un riesgo o un daño para los mismos no podrán ser sancionados en su virtud. Sin embargo, seguramente esos abandonos puedan poner en peligro la seguridad ciudadana. Es, por ello que, para lograr una mayor coherencia y evitar que conductas reprochables resulten impunes, se propone la siguiente redacción para esta infracción leve de la LOPSC: «Dejar sueltos o en condiciones de causar daños animales feroces o dañinos, así como abandonar animales domésticos en lugares públicos o privados de acceso público o en condiciones de acceder a dichos lugares».

Por lo demás, no puedo elevar a definitivas otras conclusiones, pues soy consciente de que planteo una interpretación acrobática y compleja. A mi parecer, en virtud del art. 37.16 LOPSC solo deben castigarse los abandonos físicos de animales domésticos en los espacios mencionados o en condiciones de acceder a ellos. Pues solo ese tipo de abandono -el que conlleva el surgimiento del vagabundeo- es el que pone en peligro la seguridad ciudadana. Conforme a dicha interpretación correctora que propongo, el abandono físico de un animal doméstico en un lugar público o en condiciones de acceder a él podría conllevar la imposición de dos castigos: una sanción administrativa de la LOPSC y, en su caso, una sanción administrativa de la legislación autonómica de protección animal o una pena ex art. 337 bis CP (aunque en la práctica quizás procedería matizar la regla de acumulación de castigos en virtud del principio de proporcionalidad). En el resto de supuestos (abandono asistencial o físico en lugares que no sean públicos), al sujeto únicamente se le podrá imponer la sanción autonómica o la pena en virtud de la garantía non bis in idem. La elección entre estas dos últimas dependerá, en todo caso, de la gravedad de la conducta y de si la misma es dolosa o culposa. En todos estos supuestos, seguramente también se subsumirá la conducta del sujeto infractor en el tipo de la ordenanza de convivencia ciudadana o de la ordenanza de protección animal del municipio donde se hayan producido los hechos, pero dicha norma sancionadora municipal solo será aplicable en defecto del CP, de la LOPSC y de la legislación autonómica de protección animal.

\section{REFERENCIAS BIBLIOGRÁFICAS}

ALARCÓN SOTOMAYOR, L. (2019a): "Derecho penal y derecho sancionador de la seguridad ciudadana. El proceso despenalizador", en IZQUIERDO CARRASCO, M. y ALARCÓN SOTOMAYOR, L. (dirs.): Estudios sobre la Ley Orgánica de Seguridad Ciudadana, págs. 301-348. Navarra: Aranzadi.

ALARCÓN SOTOMAYOR, L. (2019b): "Las ordenanzas de convivencia y su relación con la Ley de seguridad ciudadana: ¿Quién desplaza a quién?”, en Revista Galega de Administración Pública, núm. 57, págs. $281-309$. DOI: $h$ ttps://doi.org/10.36402/regap.v1i57.15.

ALARCÓN SOTOMAYOR, L. (2010a): "El non bis in idem como principio general del Derecho Administrativo", en SANTAMARÍA PASTOR, J. A. (dir.): Los principios jurídicos del Derecho Administrativo, págs. 387-426. Madrid: La Ley.

ALARCÓN SOTOMAYOR, L. (2010b): "Capítulo IX: Concurso de infracciones. Concurso de normas punitivas: non bis in idem”, en REBOLLO PUIG, M.; IZQUIERDO CARRASCO, M., ALARCÓN SOTOMAYOR, L. y BUENO ARMIJO, A. M. ${ }^{\text {a. }}$ Derecho Administrativo Sancionador, págs. 359-422. Valladolid: Lex Nova.

ALARCÓN SOTOMAYOR, L. (2008): La garantía non bis in idem y el procedimiento administrativo sancionador. Madrid: lustel.

CANO CAMPOS, T. (2018): Sanciones administrativas. Madrid: Francis Lefebvre.

CANO CAMPOS, T. (2001): "Non bis in idem, prevalencia de la vía penal y teoría de los concursos en Derecho Administrativo sancionador", en Revista de Administración Pública, núm. 156, págs. 191-249.

CASTRO ÁlVAREZ, C. (2019): Los animales y su estatuto jurídico: protección y utilización de los animales en el Derecho. Navarra: Aranzadi. 
REALA. Nueva Época - N. 14, octubre 2020 - ISSN: 1989-8975 - DOI: https://doi.org/10.24965/reala.i14.10852 - [Págs. 104-120]

La infracción de abandono de animales domésticos en la Ley de seguridad ciudadana y en otras disposiciones penales y administrativas..

Carmen Martín Fernández

CUGAT MAURI, M. (2014): "Abandono de un perro. Comentario a la Sentencia 235/2007, de 3 de mayo, del Juzgado de Instrucción núm. 2 de Albacete, que condena por una falta de abandono (art. 631.2 CP)", en Derecho Animal: Forum of Animal Law Studies, vol. 5, núm. 2, págs. 1-11. DOI: https://doi.org/10.5565/rev/da.135.

DEL MORAL GARCÍA, A. (dir.); ESCOBAR JIMÉNEZ, R. (coord.) (2018): Código Penal: comentarios y jurisprudencia. Granada: Comares. 4. ${ }^{a}$ ed.

DOMÉNECH PASCUAL, G. (2004): Bienestar animal contra derechos fundamentales. Barcelona: Atelier.

GÓMEZ TOMILLO, M. (dir.) (2015): Comentarios prácticos al Código Penal, Tomo IV. Navarra: Aranzadi.

HAURIOU, M. (1914): Prècis de Droit Administratif et de Droit Public. París: Sirey. 8. ${ }^{a}$ ed.

HAVA GARCÍA, E. (2011): "La protección del bienestar animal a través del Derecho Penal”, en Estudios penales y criminológicos, núm. 31, págs. 259-304.

IZQUIERDO CARRASCO, M. (2001): “La determinación de la sanción administrativa”, en Justicia Administrativa, núm. Extra 1, págs. 207-258.

MARTÍN FERNÁNDEZ, C. (2019): "El uso no autorizado de imágenes de los miembros de las Fuerzas y Cuerpos de Seguridad", en IZQUIERDO CARRASCO, M. y ALARCÓN SOTOMAYOR, L. (dirs.): Estudios sobre la Ley Orgánica de Seguridad Ciudadana, págs. 559-590. Navarra: Aranzadi.

MESÍAS RODRÍGUEZ, J. (2018): "Los delitos de maltrato y abandono de animales en el Código Penal español", en Derecho Animal: Forum of Animal Law Studies, vol. 9, núm. 2, págs. 66-105. DOI: https://doi.org/10.5565/rev/ da.324.

MUÑOZ MACHADO, S. (1999): Los animales y el Derecho. Madrid: Civitas.

NIETO GARCíA, A. (2005): Derecho Administrativo Sancionador. Madrid: Tecnos. 4. ${ }^{\text {a ed. }}$

PÉREZ MONGUIÓ, J. M. ${ }^{a}$ (2005): Animales de compañía. Barcelona: Bosch.

PIZARRO NEVADO, R. (2019): "La tutela sancionadora del patrimonio privado inmobiliario en la Ley Orgánica de Protección de la Seguridad Ciudadana", en IZQUIERDO CARRASCO, M. y ALARCÓN SOTOMAYOR, L. (dirs.): Estudios sobre la Ley Orgánica de Seguridad Ciudadana, págs. 459-499. Navarra: Aranzadi.

QUINTERO OLIVARES, G. (dir.) y MORALES PRATS, F. (coord.) (2005): Comentarios al nuevo Código Penal. Navarra: Aranzadi. 4. ${ }^{\text {a }}$ ed.

REBOLLO PUIG, M. (2019): "La trama de la Ley de Seguridad Ciudadana", en IZQUIERDO CARRASCO, M. y ALARCÓN SOTOMAYOR, L. (dirs.): Estudios sobre la Ley Orgánica de Seguridad Ciudadana, págs. 31-170. Navarra: Aranzadi.

REBOLLO PUIG, M. (2017a): "La policía local como título competencial”, en Revista Española de Derecho Administrativo, núm. 182, págs. 81-107.

REBOLLO PUIG, M. (2017b): “La actividad administrativa de limitación”, en LÓPEZ BENÍTEZ, M. e IZQUIERDO CARRASCO, M. (coords.): Derecho Administrativo, Tomo III: Modos y medios de la actividad administrativa, págs. 19-46. Madrid: Tecnos.

REBOLLO PUIG, M.; IZQUIERDO CARRASCO, M. (2005): “El régimen de infracciones y sanciones", en FERNÁNDEZ FARRERES, G. (dir.): Comentario a la Ley General de Subvenciones, págs. 597-702. Madrid: Civitas.

REBOLLO PUIG, M.; IZQUIERDO CARRASCO, M.; ALARCÓN SOTOMAYOR, L. (2007): “Tipificación de las infracciones y sanciones por las entidades locales en determinadas materias. Artículos 139-141", en REBOLLO PUIG, M. e IZQUIERDO CARRASCO, M. (coords.): Comentarios a la Ley Reguladora de las Bases de Régimen Local, Tomo 1, vol. 1, págs. 3.676-3.768. Valencia: Tirant Lo Blanch.

REBOLLO PUIG, M.; IZQUIERDO CARRASCO, M.; ALARCÓN SOTOMAYOR, L.; BUENO ARMIJO, A. M.ª (2010): Derecho Administrativo Sancionador. Valladolid: Lex Nova. 